\title{
Evaluation of the effects of Cimicifugae Rhizoma on the morphology and viability of mesenchymal stem cells
}

\author{
SU-HYEON JEONG ${ }^{1}$, JI-EUN LEE ${ }^{2}$, BO-BAE KIM ${ }^{2}$, YOUNGKYUNG KO ${ }^{2}$ and JUN-BEOM PARK ${ }^{2}$ \\ ${ }^{1}$ Department of Rehabilitation Medicine of Korean Medicine, Chungju Hospital of Korean Medicine, \\ College of Korean Medicine, Semyung University, Jecheon 390-711; ${ }^{2}$ Department of Periodontics, \\ College of Medicine, The Catholic University of Korea, Seoul 137-701, Republic of Korea
}

Received March 15, 2014; Accepted September 30, 2014

DOI: $10.3892 /$ etm.2015.2578

\begin{abstract}
Cimicifugae Rhizoma is a traditional herbal medicine used to treat various diseases in Korea, China and Japan. Cimicifugae Rhizoma is primarily derived from Cimicifuga heracleifolia Komarov or Cimicifuga foetida Linnaeus. Cimicifugae Rhizoma has been used as an anti-inflammatory, analgesic and antipyretic remedy. The present study was performed to evaluate the extracts of Cimicifugae Rhizoma on the morphology and viability of human stem cells derived from gingiva. Stem cells derived from gingiva were grown in the presence of Cimicifugae Rhizoma at final concentrations that ranged from 0.001 to $1,000 \mu \mathrm{g} / \mathrm{ml}$. The morphology of the cells was viewed under an inverted microscope and the analysis of cell proliferation was performed using a Cell Counting kit-8 (CCK-8) assay on days 1, 3, 5 and 7. Under an optical microscope, the control cells exhibited a spindle-shaped, fibroblast-like morphology. The shapes of the cells in the groups treated with $0.001,0.01,0.1,1$ and $10 \mu \mathrm{g} / \mathrm{ml}$ Cimicifugae Rhizoma were similar to the shapes in the control group. Significant alterations in morphology were noted in the 100 and $1,000 \mu \mathrm{g} / \mathrm{ml}$ groups when compared with the control group. The cells in the 100 and $1,000 \mu \mathrm{g} / \mathrm{ml}$ groups were rounder, and fewer cells were present. The cultures that were grown in the presence of Cimicifugae Rhizoma at a concentration of $0.001 \mu \mathrm{g} / \mathrm{ml}$ on day 1 had an increased CCK- 8 value. The cultures grown in the presence of Cimicifugae Rhizoma at a concentration of $10 \mu \mathrm{g} / \mathrm{ml}$ on day 7 had a reduced CCK-8 value. Within the limits of this study, Cimicifugae Rhizoma influenced the viability of stem cells derived from the gingiva, and its direct application onto oral tissues may have adverse effects at high concentrations. The concentration and application time of Cimicifugae Rhizoma should be meticulously controlled to obtain optimal results.
\end{abstract}

Correspondence to: Dr Jun-Beom Park, Department of Periodontics, College of Medicine, The Catholic University of Korea, 222 Banpo-daero, Seoul 137-701, Republic of Korea E-mail: jbassoon@hanmail.net

Key words: herbal medicine, plant roots, stem cells, cell survival

\section{Introduction}

Cimicifugae Rhizoma, also known as Seungma in Korea, Shengma in China and Shoma in Japanese is a traditional herbal medicine that is used to treat various diseases in these countries (1). Cimicifugae Rhizoma is primarily derived from Cimicifuga heracleifolia Komarov or Cimicifuga foetida Linnaeus (2). Cimicifugae Rhizoma has traditionally been used as an anti-inflammatory, analgesic and antipyretic remedy (3-6). It has been shown to induce alkaline phosphatase synthesis in rat calvarial osteoblasts when tested in vitro (7). Cimicifugae Rhizoma has also been suggested to be useful for the treatment of dental diseases, including periodontitis (8). It has demonstrated antimicrobial activity against Porphyromonas gingivalis, a common bacterium in oral biofilms, when tested in vitro (8), and has also shown chelating ability, which may be applied for the prevention of oral calcium phosphate precipitation (calculus formation) (9).

A limited study has been performed to evaluate the effects of Cimicifugae Rhizoma on cell viability (10). Cimicifugae Rhizoma extract induced $\mathrm{G}_{0} / \mathrm{G}_{1}$ cell cycle arrest of hepatocellular carcinoma at a low concentration $(25 \mu \mathrm{g} / \mathrm{ml})$, triggered $\mathrm{G}_{2} / \mathrm{M}$ arrest and apoptosis of the hepatocellular carcinoma at higher concentrations (50 and $100 \mu \mathrm{g} / \mathrm{ml}$ ) and inhibited the growth of implanted mouse tumors in a dose-dependent manner, with a growth inhibitory rate of $63.3 \%$ at $200 \mathrm{mg} / \mathrm{kg}$ (10). However, limited information is currently available regarding the effects of Cimicifugae Rhizoma on dental tissue, including mesenchymal stem cells derived from gingiva.

The aim of the present study was to evaluate the effects of extracts of Cimicifugae Rhizoma on the morphology and viability of human stem cells derived from gingiva. To the best of our knowledge, this study is the first to elucidate the effect of Cimicifugae Rhizoma on stem cells derived from gingiva.

\section{Materials and methods}

Preparation of materials. The dry roots of Cimicifuga heracleifolia Komarov (500 g; Chungju Hospital of Korean Medicine, College of Korean Medicine, Semyung University, Chungju, Republic of Korea) were immersed in distilled water and boiled under reflux for $2 \mathrm{~h} 30 \mathrm{~min}$, and the resulting extract was centrifuged at $5,000 \mathrm{x} \mathrm{g}$ for $10 \mathrm{~min}$. The supernatant 

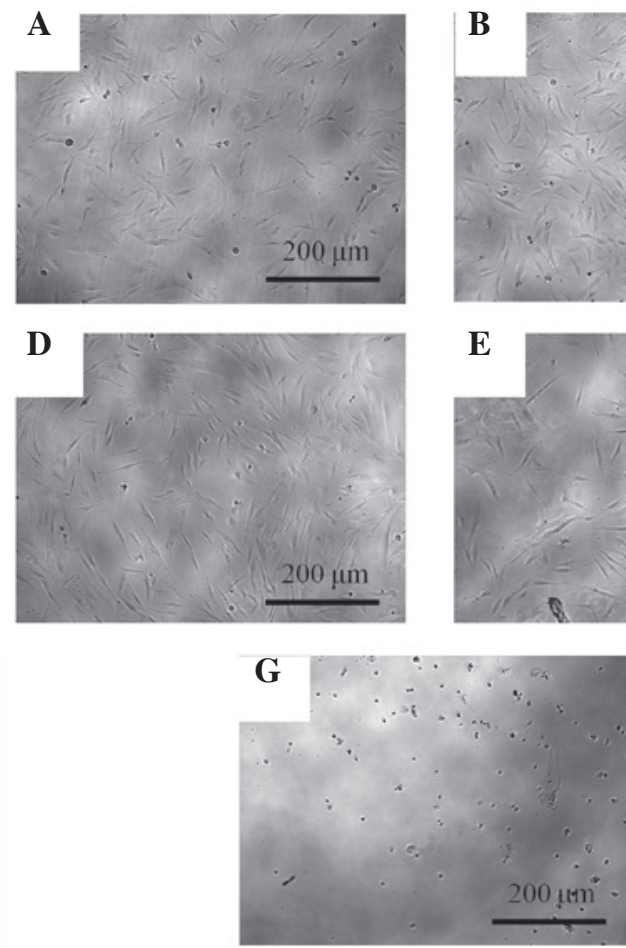

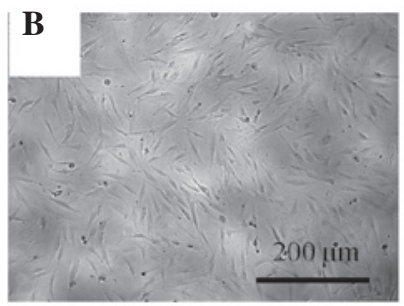

$\mathbf{E}$

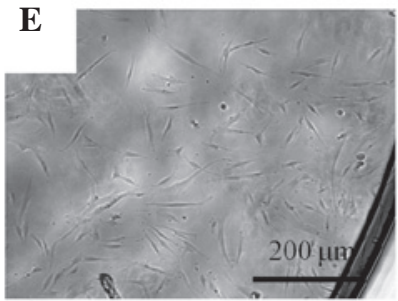

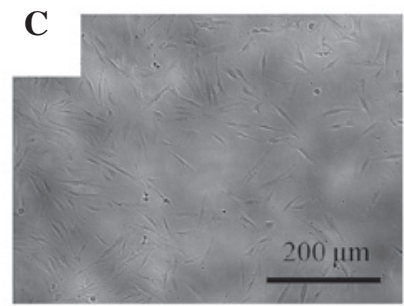

$\mathbf{F}$

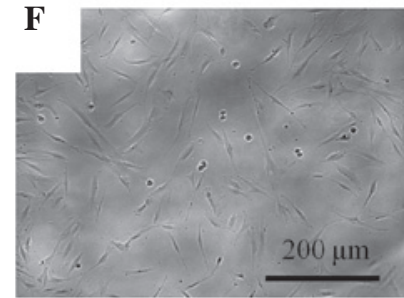

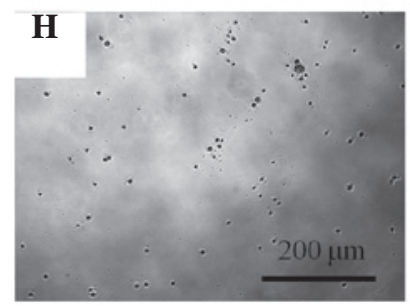

Figure 1. Evaluation of cell morphology on day 1. (A) Control and (B) $0.001 \mu \mathrm{g} / \mathrm{ml}$, (C) $0.01 \mu \mathrm{g} / \mathrm{ml}$, (D) $0.1 \mu \mathrm{g} / \mathrm{ml}$, (E) $1 \mu \mathrm{g} / \mathrm{ml}$, (F) $10 \mu \mathrm{g} / \mathrm{ml}$, (G) $100 \mu \mathrm{g} / \mathrm{ml}$ and $(\mathrm{H}) 1,000 \mu \mathrm{g} / \mathrm{ml}$ Cimicifugae Rhizoma treatment groups.

was concentrated to $300 \mathrm{ml}$ using a rotary evaporator under reduced pressure (Eyela NE-1001; Tokya Rikakikai Co., Ltd, Tokyo, Japan). The concentrates were then freeze-dried using a lyophilizer (Labconco, Kansas, MO, USA) to obtain $92.8 \mathrm{~g}$ solid residue, resulting in a yield of $18.6 \%(\mathrm{w} / \mathrm{w})$.

Isolation and culture of stem cells derived from gingiva. Healthy gingival tissues were obtained from healthy patients undergoing crown-lengthening procedures. This study was reviewed and approved by the Institutional Review Board of Seoul St. Mary's Hospital, College of Medicine, The Catholic University of Korea (Seoul, Korea; KC11SISI0348), and informed consent was obtained from all patients.

The tissues were immediately placed in sterile phosphate-buffered saline (PBS; Welgene, Inc., Daegu, Korea) with $100 \mathrm{U} / \mathrm{ml}$ penicillin, and $100 \mu \mathrm{g} / \mathrm{ml}$ streptomycin (Sigma-Aldrich, St. Louis, MO, USA) at $4^{\circ} \mathrm{C}$. The gingival tissue was de-epithelialized, minced, digested with collagenase IV (Sigma-Aldrich) and incubated at $37^{\circ} \mathrm{C}$ in a humidified incubator with $5 \% \mathrm{CO}_{2}$ and $95 \% \mathrm{O}_{2}$. The non-adherent cells were washed with PBS after $24 \mathrm{~h}$, supplied with essential minimal medium $\alpha$ ( $\alpha$-MEM; Gibco Life Technologies, Grand Island, NY, USA) containing $15 \%$ fetal bovine serum (Gibco), $100 \mathrm{U} / \mathrm{ml}$ penicillin, and $100 \mu \mathrm{g} / \mathrm{ml}$ streptomycin (Sigma-Aldrich), $200 \mathrm{mM}$ L-glutamine (Sigma-Aldrich) and $10 \mathrm{mM}$ ascorbic acid 2-phosphate (Sigma-Aldrich), and fed every 2-3 days. These cells showed the characteristics of stem cells, including colony-forming abilities, plastic adherence and multi-lineage differentiation (osteogenic, adipogenic, chondrogenic) potency. Approximately $3 \times 10^{5}$ cells were incubated with specific PE-, APC-, BV421-, PerCP-cyTM5.5- or fluorescein isothiocyanate-conjugated mouse monoclonal antibodies for human CD44, CD73, CD90, CD105, CD14, CD45, CD34 and CD19 (BD Biosciences, San Jose, CA, USA). The cells expressed CD44, CD73, CD90 and CD105, but did not express CD14, CD45, CD34 and CD19 when examined by flow cytometry (FACSCanto II; BD Biosciences).

Evaluation of stem cell morphology. The stem cells were plated at a density of $2.0 \times 10^{3}$ cells/well in 96-well plates. The cells were incubated in $\alpha$-MEM (Gibco Life Technologies, Grand Island, NY, USA) that was composed of $15 \%$ fetal bovine serum (Gibco Life Technologies), $100 \mathrm{U} / \mathrm{ml}$ penicillin, $100 \mu \mathrm{g} / \mathrm{ml}$ streptomycin, $200 \mathrm{mM} \mathrm{L}$-glutamine (Sigma-Aldrich) and $10 \mathrm{mM}$ ascorbic acid 2-phosphate (Sigma-Aldrich) in the presence of the Cimicifugae Rhizoma extract at final concentrations that ranged from 0.001 to $1,000 \mu \mathrm{g} / \mathrm{ml}$. The concentrations used were 0 (untreated control), 0.001, 0.01, 0.1, $1,10,100$ and $1,000 \mu \mathrm{g} / \mathrm{ml}$, respectively. The morphology of the cells was viewed under an inverted microscope (Leica DM IRM; Leica Microsystems, Wetzlar, Germany) on days 1, 3, 5 and 7. The images were saved as JPEG files.

Determination of cell proliferation. The analysis of cell proliferation was performed on days 1,3,5 and 7. Viable cells were identified using a Cell Counting kit-8 (CCK-8; Dojindo Molecular Technologies, Inc.) assay. The spectrophotometric absorbance was measured with a Synergy MX microplate reader (BioTek Instruments, Inc.; Winooski, VT, USA), and the analysis was performed in triplicate.

Statistical analysis. The results are represented as the means \pm standard deviation. A test of normality was performed, and a one-way analysis of variance (ANOVA) with post hoc 

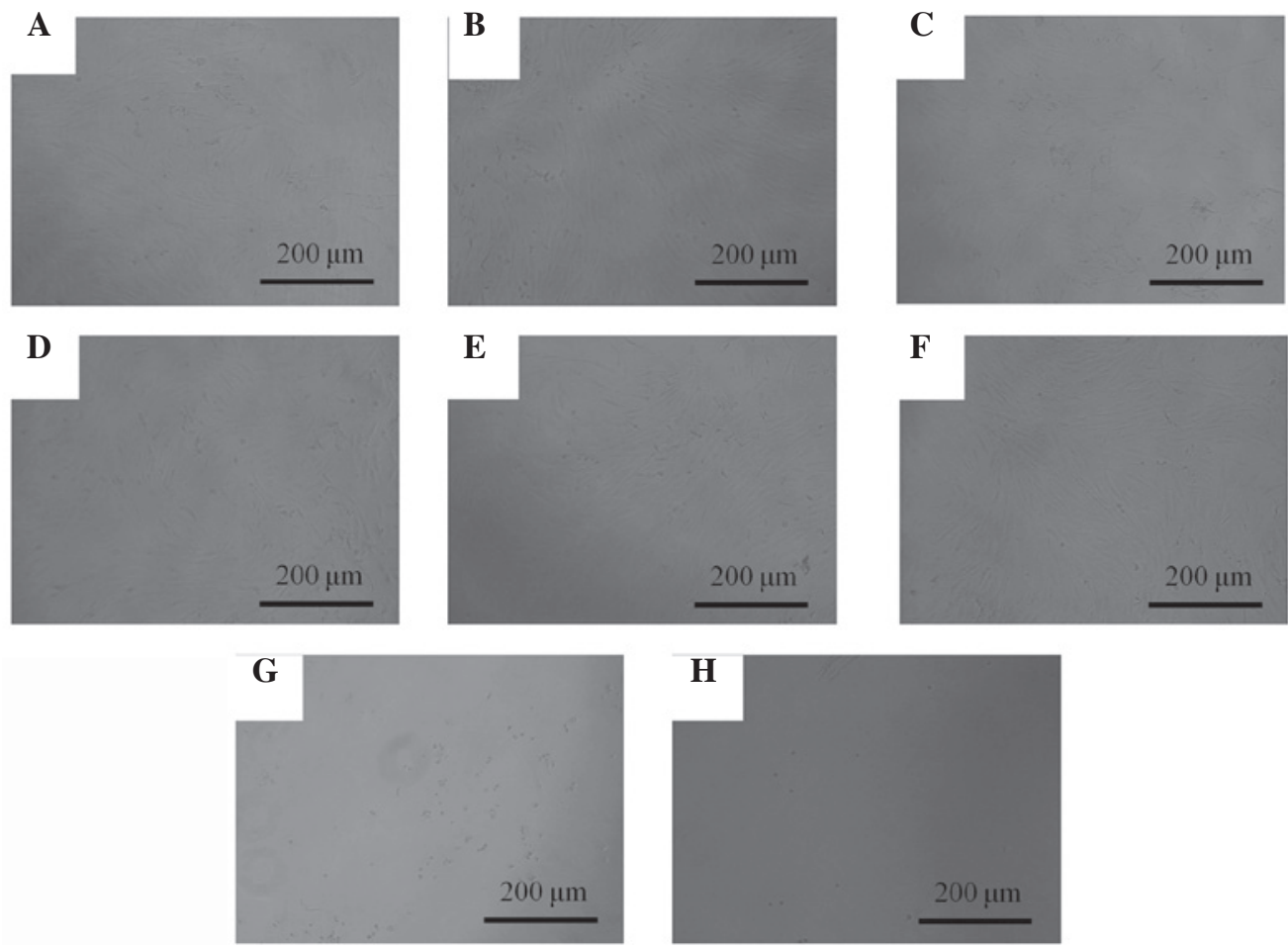

Figure 2. Cell morphology on day 3. (A) Control and (B) $0.001 \mu \mathrm{g} / \mathrm{ml}$, (C) $0.01 \mu \mathrm{g} / \mathrm{ml}$, (D) $0.1 \mu \mathrm{g} / \mathrm{ml}$, (E) $1 \mu \mathrm{g} / \mathrm{ml},(\mathrm{F}) 10 \mu \mathrm{g} / \mathrm{ml},(\mathrm{G}) 100 \mu \mathrm{g} / \mathrm{ml}$ and (H) $1,000 \mu \mathrm{g} / \mathrm{ml}$ Cimicifugae Rhizoma treatment groups.
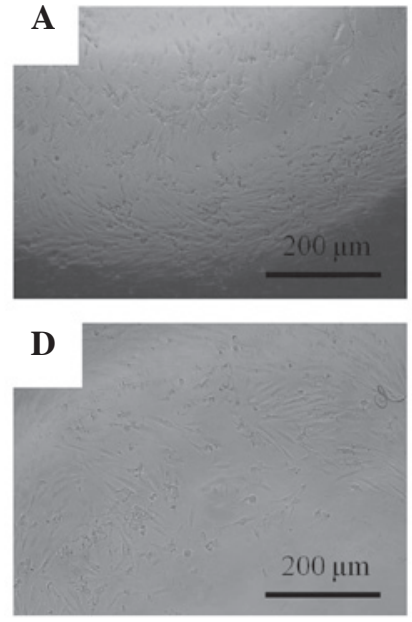
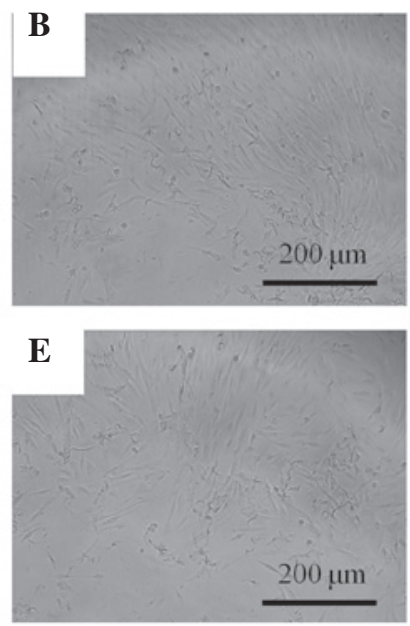
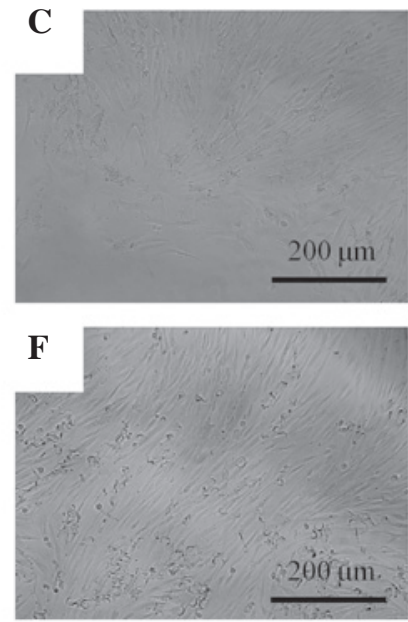

Figure 3. Cell morphology on day 5. (A) Control and (B) $0.001 \mu \mathrm{g} / \mathrm{ml}$, (C) $0.01 \mu \mathrm{g} / \mathrm{ml}$, (D) $0.1 \mu \mathrm{g} / \mathrm{ml}$, (E) $1 \mu \mathrm{g} / \mathrm{ml}$ and (F) $10 \mu \mathrm{g} / \mathrm{ml} \mathrm{Cimicifugae} \mathrm{Rhizoma}$ treatment groups.

test was performed to determine the differences between the groups using commercially available software (SPSS version 12 for Windows; SPSS, Inc., Chicago, IL, USA). P $<0.05$ was considered to indicate a statistically significant difference.

\section{Results}

Evaluation of cell morphology. The morphology of the stem cells at day 1 is shown in Fig. 1. Under an optical microscope, the control group showed spindle-shaped, fibroblast-like morphology. The shapes of the cells treated with $0.001-10 \mu \mathrm{g} / \mathrm{ml}$ Cimicifugae Rhizoma were similar to the shapes of the control group. Significant alterations were noted in the 100 and $1,000 \mu \mathrm{g} / \mathrm{ml}$ groups when compared with the control group. The shapes of the cells in the 100 and $1,000 \mu \mathrm{g} / \mathrm{ml}$ groups were rounder, and fewer cells were present.

The morphology of the cells on day 3 is shown in Fig. 2 . The shapes of the cells in treated with $0.001-10 \mu \mathrm{g} / \mathrm{ml}$ were similar to the shapes of the control group. Marked alterations in cytoskeletal organization were observed in the 100 and $1,000 \mu \mathrm{g} / \mathrm{ml}$ groups. The shapes of the cells in the 100 and $1000 \mu \mathrm{g} / \mathrm{ml}$ groups were rounder, and fewer cells were present, when compared with the control group.

The morphology of the cells on days 5 and 7 is shown in Figs. 3 and 4, respectively. The shapes of the cells in the 

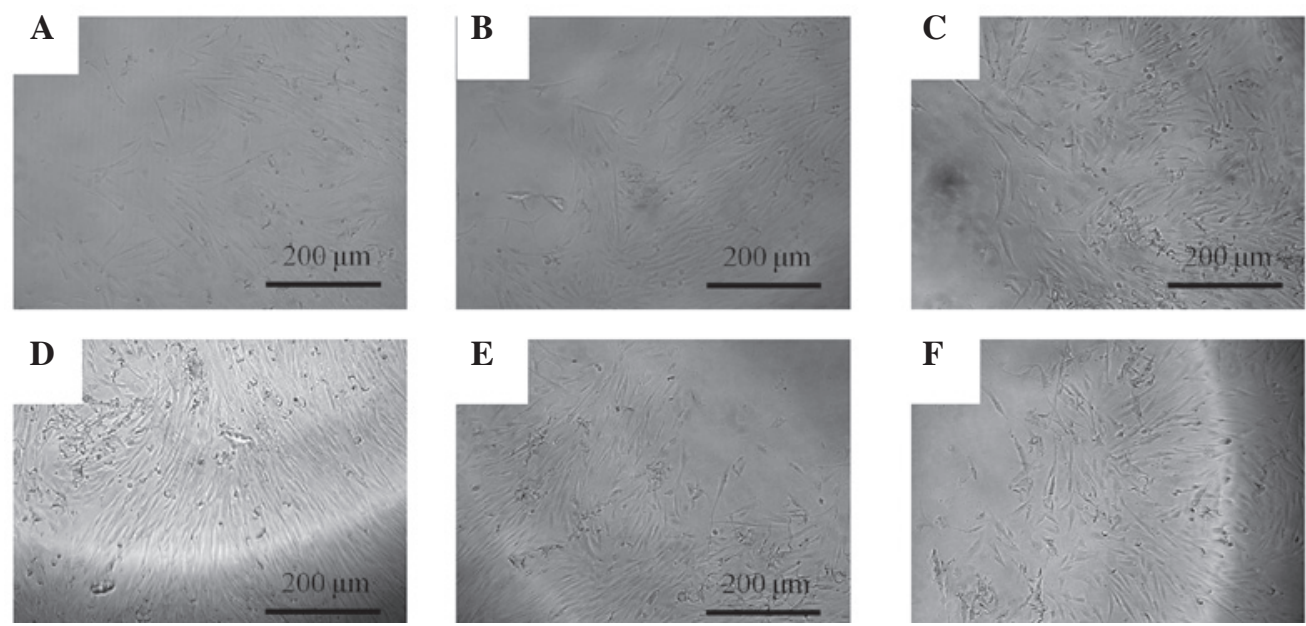

Figure 4. Cell morphology on day 7. (A) Control and (B) $0.001 \mu \mathrm{g} / \mathrm{ml}$, (C) $0.01 \mu \mathrm{g} / \mathrm{ml}$ group. (D) $0.1 \mu \mathrm{g} / \mathrm{ml}$, (E) $1 \mu \mathrm{g} / \mathrm{ml}$ group and (F) $10 \mu \mathrm{g} / \mathrm{ml} \mathrm{Cimicifugae}$ Rhizoma treatment groups.

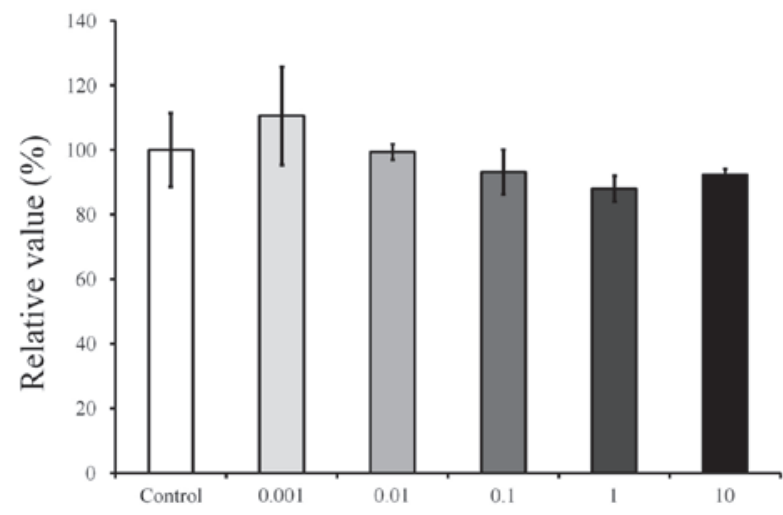

Figure 5. Cellular viability on day 1 .

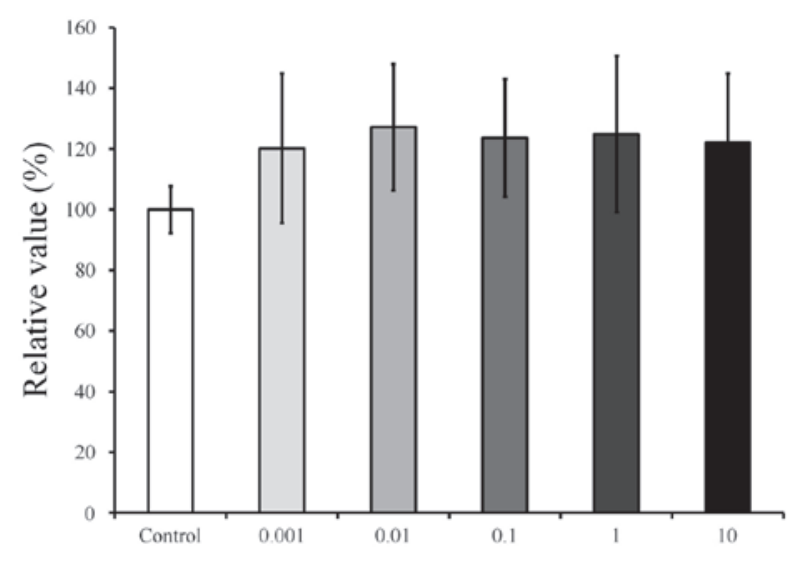

Figure 6. Cellular viability on day 3.

$0.001-10 \mu \mathrm{g} / \mathrm{ml}$ groups were similar to the shapes of the untreated control group.

Cell proliferation. The results of the cell proliferation assay on days 1, 3, 5 and 7 are shown in Fig. 5, 6, 7 and 8, respectively. The cultures that were grown in the presence of Cimicifugae Rhizoma on day 1 showed an increase in the CCK- 8 result at $0.001 \mu \mathrm{g} / \mathrm{ml}$ (Fig. 5). The relative value of the CCK-8 assay

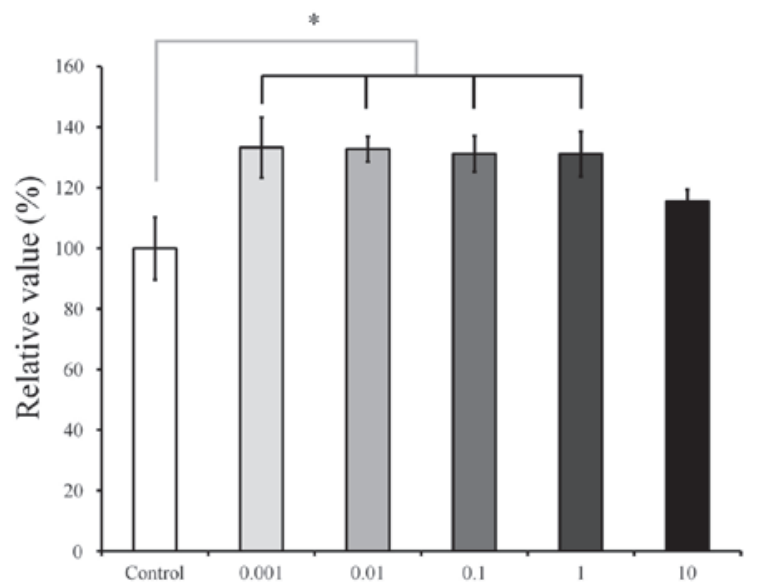

Figure 7. Cellular viability on day 5. ${ }^{*} \mathrm{P}<0.05$, statistically significant differences between the control and treatment groups.

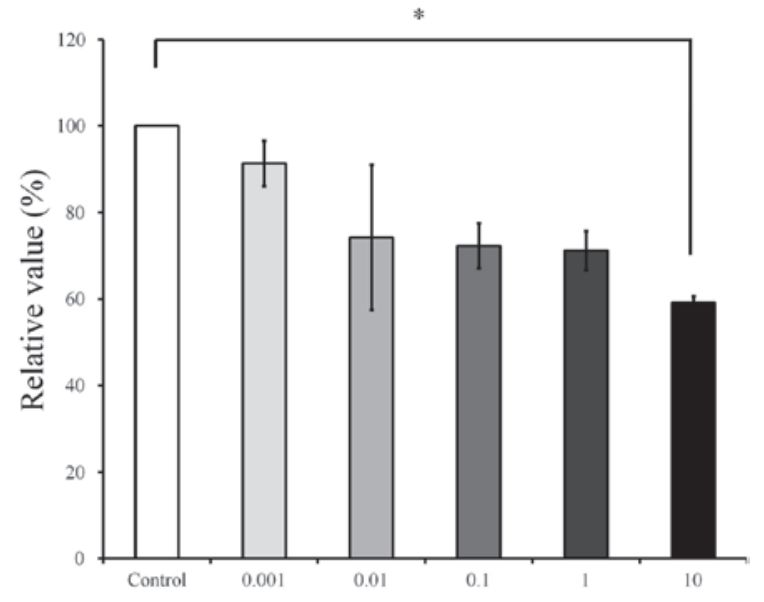

Figure 8 . Cellular viability on day $7 .{ }^{*} \mathrm{P}<0.05$, statistically significant differences between the control and treatment groups.

result for $0.001 \mu \mathrm{g} / \mathrm{ml}$ Cimicifugae Rhizoma was $110.6 \pm 15.2 \%$, when the CCK-8 result of the untreated control group on day 1 was considered to be $100 \%$; however, there were no significant differences $(\mathrm{P}>0.05)$. On day 3 (Fig. 6), the relative value of 
the CCK- 8 result for $0.001 \mu \mathrm{g} / \mathrm{ml}$ Cimicifugae Rhizoma was $120.2 \pm 24.6 \%$, when the CCK-8 result of the untreated control group on day 3 was considered to be $100 \%$. On day 5 (Fig. 7), the cultures grown in the presence of Cimicifugae Rhizoma at concentrations of $0.001,0.01,0.1$ and $1 \mu \mathrm{g} / \mathrm{ml}$ resulted in increased CCK- 8 values $(\mathrm{P}<0.05)$. The relative values of the CCK-8 results for $0.001,0.01,0.1,1$ and $10 \mu \mathrm{g} / \mathrm{ml}$ Cimicifugae Rhizoma were $133.3 \pm 10.0,132.7 \pm 4.2,131.2 \pm 5.8,131.2 \pm 7.3$ and $115.5 \pm 4.0 \%$, respectively, when the CCK- 8 result of the untreated control group on day 5 was considered to be $100 \%$ $(100.0 \pm 7.7 \%$ ). On day 7 (Fig. 8), The relative value of the CCK-8 result for $10 \mu \mathrm{g} / \mathrm{ml}$ Cimicifugae Rhizoma was $59.2 \pm 1.5 \%$, when the CCK- 8 result of the untreated control group on day 7 was considered to be $100 \%(\mathrm{P}<0.05)$.

\section{Discussion}

In this study, the effects of Cimicifugae Rhizoma on the morphology and proliferation of human mesenchymal stem cells derived from periodontal tissue were investigated. The results clearly demonstrated that the stem cells were sensitive to Cimicifugae Rhizoma at high concentrations and that a significant reduction in cellular viability occurred at 100 and $1,000 \mu \mathrm{g} / \mathrm{ml}$ concentrations.

The effects of Cimicifugae Rhizoma have previously been tested in in vitro and in vivo experiments (10-12). A Cimicifugae Rhizoma extract has shown cytotoxicity toward human cancer cell lines, including promyelocytic, lung carcinoma and human colon adenocarcinoma cell lines (12). The cytotoxicity of Cimicifugae Rhizoma has been tested and the half maximal inhibitory concentration $\left(\mathrm{IC}_{50}\right)$ values on hepatocellular carcinoma and drug-resistant hepatocellular carcinoma cell lines and primary cultured normal mouse hepatocytes were found to be 21,43 and $80 \mu \mathrm{g} / \mathrm{ml}$, respectively (10). In a rat model, Cimicifugae Rhizoma extract at a dosage of $50 \mathrm{mg} / \mathrm{kg}$ showed a slight toxicity in the liver and kidney via disturbance of the metabolisms of energy and amino acids, which provides a reasonable explanation for the clinical hepatotoxicity (11).

Cimicifugae Rhizoma is a traditional herbal medicine used to treat various diseases. The anticancer properties of plants of the genus Cimicifuga have received considerable attention in recent years (12). Cimicifugae Rhizoma can be used for the treatment of cardiovascular disorders such as atherosclerosis (13). Ovariectomized rats treated with extracts of Cimicifugae Rhizoma exhibited a significant increase in bone mineral density compared with that in untreated rats (2), and it was suggested that these anti-bone resorption effects of Cimicifugae Rhizoma may be applied therapeutically against osteoporosis $(14,15)$. Aqueous extracts of Cimicifugae Rhizoma have shown central nervous system effects by binding to the 5-HT1A receptor (4). Cimicifugae Rhizoma has also demonstrated inhibitory effects on histamine, bradykinin and COX-2-mediated inflammatory actions (5). The analgesic and sedative effects of Cimicifugae Rhizoma have been noted using animal model experiments (16). As an effective antioxidant, Cimicifugae Rhizoma can protect deoxyribonucleic acid and lipids against oxidative damage, and its antioxidant ability may be responsible for its various pharmacological effects (17). Cimicifugae Rhizoma has also been reported to protect the intestines and hematopoietic organs against radiation damage (18). A herbal drug containing multiple medicinal plants, including Cimicifugae Rhizoma, has demonstrated the ability to decrease bacterial counts in urine culture (19), and Cimicifugae Rhizoma has also shown an antiviral effect (20).

There is great interest in stem cells due to their promising potential for the treatment of diseases and the regeneration of tissue (21). Stem cells may be obtained from various tissues, including bone marrow and adipose tissue $(22,23)$. Moreover, stem cells may be obtained intraorally, including from dental pulp and periodontal ligaments $(24,25)$. However, tissue obtained intraorally may not be easily accessible, and only a limited amount of the tissue can be obtained in a limited number of procedures. By contrast, the gingiva is an readily accessible tissue source (26). Thus, stem cells derived from gingiva may be useful for the research and treatment of disease.

Within the limits of the present study, Cimicifugae Rhizoma influenced the viability of stem cells derived from gingiva, and its direct application onto oral tissues may produce adverse effects at high doses. The concentration and application time of Cimicifugae Rhizoma should be meticulously controlled to obtain optimal results.

\section{Acknowledgements}

This research was supported by the Basic Science Research Program through the National Research Foundation of Korea (NRF) funded by the Ministry of Science, ICT and Future Planning (NRF-2014R1A1A1003106).

\section{References}

1. Kim CM, Shin MK, Lee KS and Ahn DK (eds). The Encyclopedia of Oriental Herbal Medicine. Jung Dam Publishing Co., Seoul. 1998. pp3362-3372, 1998.

2. Li JX, Kadota S, Li HY, et al: Effects of Cimicifugae rhizoma on serum calcium and phosphate levels in low calcium dietary rats and on bone mineral density in ovariectomized rats. Phytomedicine 3: 379-385, 1997.

3. Sakurai $\mathrm{N}$ and Nagai $\mathrm{M}$ : Chemical constituents of original plants of Cimicifugae rhizoma in Chinese medicine. Yakugaku Zasshi 116: 850-865, 1996 (In Japanese).

4. Liao JF, Jan YM, Huang SY, Wang HH, Yu LL and Chen CF: Evaluation with receptor binding assay on the water extracts of ten CNS-active Chinese herbal drugs. Proc Natl Sci Counc Repub China B 19: 151-158, 1995.

5. Kim SJ and Kim MS: Inhibitory effects of cimicifugae rhizoma extracts on histamine, bradykinin and COX-2 mediated inflammatory actions. Phytother Res 14: 596-600, 2000.

6. Kwon IH, Kim NK, Chiang HC, Lim HG and Kim JM. Antipyretic effect of Rhizoma Cimicifugae in a rat model of LPS-induced fever. Daehan Hanui Hakhoeji 23: 32-44, 2002 (In Korean).

7. Kim DK, Kim T, Pi SH, et al: Effects of several natural medicines on alkaline phosphatase synthesis in MC3T3-E1 cells. J Korean Acad Periodontol 29: 751-764, 1999.

8. Wong RW, Hägg U, Samaranayake L, Yuen MK, Seneviratne CJ and Kao R: Antimicrobial activity of Chinese medicine herbs against common bacteria in oral biofilm. A pilot study. Int J Oral Maxillofac Surg 39: 599-605, 2010.

9. Hidaka S, Nishimura H, Nakajima K and Liu SY: Effects of a rhubarb (Rhei rhizoma) solution and its fractions on the formation of calcium phosphate precipitates. J Periodontal Res 31: 408-413, 1996.

10. Tian Z,Pan R, Chang Q, Si J, Xiao P and Wu E: Cimicifuga foetida extract inhibits proliferation of hepatocellular cells via induction of cell cycle arrest and apoptosis. J Ethnopharmacol 114: 227-233, 2007.

11. He CC, Dai YQ, Hui RR, et al: NMR-based metabonomic approach on the toxicological effects of a Cimicifuga triterpenoid. J Appl Toxicol 32: 88-97, 2012. 
12. Lu L, Chen JC, Li Y, et al: Studies on the constituents of Cimicifuga foetida collected in Guizhou Province and their cytotoxic activities. Chem Pharm Bull (Tokyo) 60: 571-577, 2012.

13. Mun L, Jun MS, Kim YM, et al: 7,8-didehydrocimigenol from Cimicifugae rhizoma inhibits TNF- $\alpha$-induced VCAM-1 but not ICAM-1expression through upregulation of PPAR- $\gamma$ in human endothelial cells. Food Chem Toxicol 49: 166-172, 2011.

14. Li JX and Yu ZY: Cimicifugae Rhizoma: from origins, bioactive constituents to clinical outcomes. Curr Med Chem 13: 2927-2951, 2006.

15. Li JX, Liu J, He CC, et al: Triterpenoids from Cimicifugae rhizoma, a novel class of inhibitors on bone resorption and ovariectomy-induced bone loss. Maturitas 58: 59-69, 2007.

16. Cao L, Sun H, Li Z and Pan RL: Comparison of activities of various species of Rhizoma Cimicifugae and their honey processed products. Zhong Yao Cai 30: 1561-1563, 2007 (In Chinese).

17. Li X, Lin J, Gao Y, Han W and Chen D: Antioxidant activity and mechanism of Rhizoma Cimicifugae. Chem Cent J 6: 140, 2012.

18. Kim SH, Lee SE, Oh H, et al: The radioprotective effects of Bu-Zhong-Yi-Qi-Tang: a prescription of traditional Chinese medicine. Am J Chin Med 30: 127-137, 2002.

19. Nishida S: Effect of Hochu-ekki-to on asymptomatic MRSA bacteriuria. J Infect Chemother 9: 58-61, 2003.

20. Pan L, Huang YW, Ye YR and Wang YQ: A model for screening anti-viral agents based on yeast killer system. Wei Sheng Wu Xue Bao 47: 517-521, 2007 (In Chinese).
21. Sekiya I, Larson BL, Smith JR, Pochampally R, Cui JG and Prockop DJ: Expansion of human adult stem cells from bone marrow stroma: conditions that maximize the yields of early progenitors and evaluate their quality. Stem Cells 20: 530-541, 2002.

22. Kuznetsov SA, Friedenstein AJ and Robey PG: Factors required for bone marrow stromal fibroblast colony formation in vitro. $\mathrm{Br}$ J Haematol 97: 561-570, 1997.

23. Rodriguez AM, Elabd C, Amri EZ, Ailhaud G and Dani C: The human adipose tissue is a source of multipotent stem cells. Biochimie 87: 125-128, 2005.

24. Ballini A, De Frenza G, Cantore S, Papa F, Grano M, Mastrangelo $F$, Tetè $S$ and Grassi FR: In vitro stem cell cultures from human dental pulp and periodontal ligament: new prospects in dentistry. Int J Immunopathol Pharmacol 20: 9-16, 2007.

25. Nagatomo K, Komaki M, Sekiya I, Sakaguchi Y, Noguchi K, Oda S, Muneta T and Ishikawa I: Stem cell properties of human periodontal ligament cells. J Periodontal Res 41: 303-310, 2006

26. Zhang Q, Shi S, Liu Y, Uyanne J, Shi Y, Shi S and Le AD: Mesenchymal stem cells derived from human gingiva are capable of immunomodulatory functions and ameliorate inflammation-related tissue destruction in experimental colitis. J Immunol 183: 7787-7798, 2009. 